\title{
Respon Akar Bibit Kelapa Sawit (Elaeis guineensis) Di Pre Nursery Pada Pemberian Naungan dan Abu Janjang Kelapa Sawit
}

\section{Response of Root Oil Palm Seeds (Elaeis guineensis) In Pre Nursery On Giving Shade and Oil Palm Bunch Ash}

\author{
Yetti Elidar \\ Tenaga Pendidikan Program Studi Agroteknologi, Fakultas Pertanian, Universitas Mulawarman Jl. Pasir Balengkong \\ Kota Samarinda, Kalimantan Timur 75117 \\ email : elidaryetti@gmail.com
}

Diterima : 24 Agustus 2017 Disetujui : 12 Oktober 2017

\begin{abstract}
The aim of this research is to know the effect of shade and dosage of palm oil ash as well as their interaction to the root of oil palm plantation in pre nursery. This research was carried out in Nursery Faculty of Agriculture, Mulawarman University, Samarinda from February to May 2011. This research is an experiment arranged in Completely Random Design (RAL) with split plot analysis $\left(\begin{array}{l}4 \\ x\end{array}\right)$ with 5 replications. The main plot is the level of shade reduction (N) at the age of 10 weeks which consists of four levels, namely: no = Shade minus $100 \%$, n1= Shade minus 75\%, n2 = Shade minus 50\%, n3 = Shade minus 25\%. As a plot child is a dose of ash (D) consisting of four levels: $d 1=11.5 \mathrm{~g}$ of ash / polybag equivalent to 23 tons / ha, d2 = $23 \mathrm{~g}$ of ash / polybag equivalent to 45 tons / ha, d3 = $34.5 \mathrm{~g}$ of ash / polybag equivalent to 68 tons / ha, d4 = 45 g of ash / polybag equivalent of 91 tons / ha. Data were analyzed statistically and tested further with the smallest real difference test (BNT) at 5\% level. The results showed that the treatment of ash dose $23 \mathrm{~g}$ ash / polybag or equal to 45 ton / ha (d2) gave wet weight, dry weight, wet weight of leaf, average dry weight of leaves $5,51 \mathrm{~g}, 2,32 \mathrm{~g}$, and $5.08 \mathrm{~g}$. The shading treatment gives a mean wet weight of roots $1.90 \mathrm{~g}$.
\end{abstract}

Keywords: oil palm, shade and gray ash

\section{PENDAHULUAN}

Kalimantan Timur merupakan salah satu daerah yang mempunyai potensi pengembangan perkebunan kelapa sawit yang ideal. Berdasarkan data Dinas Perkebunan (Disbun) Kaltim, diperkirakan luas areal perkebunan kelapa sawit meningkat dari 171.581 hektar pada tahun 2004 menjadi 530.555 hektar pada tahun 2009, dengan pertumbuhan rata-rata $41.84 \%$ pertahun. Sedangkan, mengenai produksi yang telah meningkat dari 957.058 ton pada tahun 2004 menjadi 2,29 juta ton pada tahun 2009 atau terdapat peningkatan produksi sebesar $28,03 \%$.

Seiring dengan pesatnya pembukaan areal perkebunan kelapa sawit yang terus meningkat maka dibutuhkan bibit yang mempunyai kualitas terbaik yang mampu memberikan pertumbuhan terbaik. Dalam hal ini dibutuhkan penanganan yang serius dalam pembibitan kelapa sawit terutama pada pembibitan awal (Pre nursery). Pada masa pembibitan awal perlakuan dipusatkan pada media tanam dan kondisi lingkungan sekitar meliputi intensitas dan kelembaban.

Abu janjang kelapa sawit merupakan limbah dari pabrik pengolahan minyak kelapa sawit. Limbah padat tandan kosong sawit (TKS) di Indonesia diperkirakan mencapai 27 juta ton pada tahun 1999. Limbah ini berpotensi untuk dimanfaatkan menjadi produk-produk yang bernilai produksi lebih tinggi. Salah satu pemanfaatan TKS adalah sebagai pupuk (bahan pembenah tanah). Potensi TKS sebagai pupuk berkaitan dengan materi TKS yang merupakan bahan organik dengan kandungan hara cukup tinggi. Dari hasil analisis menunjukan bahwa TKS memiliki kandungan hara sebesar 2,90\% $\mathrm{K}_{2} \mathrm{O}, 0,80 \% \mathrm{~N}, 0,22 \% \mathrm{P}_{2} \mathrm{O}_{5}, 0,30 \% \mathrm{MgO}$ dan unsur-unsur mikro antara lain10 ppm B, dan 23 ppm Cu (Sigit, 2003).

Menurut Rosyadi (2009), Unsur hara separti Nitrogen (N), Fospor (P), dan Kalium (K) tidak selalu terdapat didalam tanah top soil dalam jumlah yang cukup, dalam hal ini perlu adanya pemberian unsur hara tambahan ke dalam tanah untuk memenuhi kekurangan unsur hara yang dibutuhkan. Dalam hal ini abu janjang dapat digunakan sebagai salah satu pelengkap unsur hara.

Asmono, (2003) menerangkan bahwa selain tanah yang berkualitas baik, naungan juga mempunyai peranan yang penting dalam pembibitan awal, karena bibit kelapa sawit berada dalam tahap vegetatif. Naungan berfungsi untuk mencegah bibit kelapa sawit terhadap terpaan sinar matahari secara langsung dan menjaga kelembapan. Selain itu, naungan 
juga berfungsi untuk menghindari terbongkarnya tanah di polibag akibat terpaan air hujan.

Besarnya intensitas cahaya matahari yang jatuh ke permukaan bumi dapat diatur dengan pemberian naungan. Bibit kelapa sawit pada pembibitan awal memerlukan naungan $100 \%$ pada umur $0-1,5$ bulan dan akan dikurangi secara bertahap sampai menjadi $100 \%$ terbuka atau tanpa naungan pada umur 3 bulan. Pengaturan tingkat kerapatan naungan diperlukan untuk mengatur intensitas cahaya sesuai dengan kebutuhan bibit kelapa sawit (Asmono, 2003).Kebutuhan cahaya untuk setiap

\section{BAHAN DAN METODE}

Penelitian ini dilaksanakan selama 4 bulan yaitu mulai dari bulan Februari sampai dengan Mei 2011. Lokasi percobaan di lahan Screen House Faperta Unmul, Samarinda.. Bahan yang digunakan benih kelapa sawit, furadan $3 \mathrm{G}$, polibag ukuran $1 \mathrm{~kg}$, tanah top soil, pasir, abu janjang, paranet $25 \%$ dan kayu. Penelitian ini merupakan percobaan yang disusun dalam Rancangan Acak Lengkap (RAL) dengan analisis split plot (4 x 4) dengan 5 kali ulangan. Petak utama adalah tingkat pengurangan naungan $(\mathrm{N})$ pada umur 10 minggu yang terdiri dari empat taraf, yaitu : no $=$ Naungan dikurangi $100 \%, \mathrm{n}_{1}=$ Naungan dikurangi $75 \%, \mathrm{n}_{2}=$ Naungan dukurangi $50 \%, \mathrm{n}_{3}=$ Naungan dikurangi $25 \%$. Sebagai anak petak adalah dosis abu janjang (D) yang terdiri dari empat taraf yaitu $: \mathrm{d}_{1}=11,5 \mathrm{~g}$ abu janjang / polybag

\section{HASIL DAN PEMBAHASAN}

\section{Bobot Basah Tanaman}

Hasil sidik ragam menunjukkan bahwa perlakuan naungan $(\mathrm{N})$ berpengaruh tidak nyata, tetapi perlakuan abu janjang (D) memberikan pengaruh nyata terhadap rata-rata bobot basah. Hasil uji BNT 5\% menunjukkan bahwa pada perlakuan abu janjang (D) perlakuan $\mathrm{d}_{1}$ berbeda nyata dengan perlakuan $d_{2}$ dan $d_{3}$ tetapi berbeda tidak nyata terhadap perlakuan $\mathrm{d}_{4}$. Perlakuan $\mathrm{d}_{2}$ berbeda nyata dengan perlakuan $d_{3}, d_{4}$ dan $d_{1}$. Perlakuan $\mathrm{d}_{3}$ berbeda nyata terhadap perlakuan $\mathrm{d}_{4}, \mathrm{~d}_{1}$ dan $\mathrm{d}_{2}$. Perlakuan $\mathrm{d}_{4}$ berbeda nyata terhadap perlakuan $d_{2}$ dan $d_{3}$ tetapi berbeda tidak nyata terhadap perlakuan $d_{1}$. Rata-rata bobot batang dan panjang pelepah) dan kondisi fisik jenis tanaman berbeda, Pada jenis tanaman yang membutuhkan cahaya, naungan yang terlalu rapat akan menyebabkan terjadinya etiolasi. Naungan yang kurang rapat akan menyebabkan kurangnya perlindungan bagi tanaman (bibit) dari sinar matahari langsung, curah hujan yang tinggi, angin serta fluktuasi suhu yang ekstrim (Schmidt, 2002).

Berdasarkan uraian tersebut, maka penulis merasa perlu melakukan penelitian untuk mengetahui pengaruh naungan dan abu janjang terhadap pertumbuhan akar tanaman kelapa sawit pada pembibitan awal (Pre-nursery).

setara dengan 23 ton $/ \mathrm{ha}, \mathrm{d}_{2}=23 \mathrm{~g}$ abu janjang / polybag setara dengan 45 ton/ha, $\mathrm{d}_{3}=34,5 \mathrm{~g}$ abu janjang / polybag setara dengan 68 ton/ha, $\mathrm{d}_{4}=45 \mathrm{~g}$ abu janjang / polybag setara dengan 91 ton/ha. Dengan demikian terdapat 12 perlakuan dan setiap perlakuan diulang sebanyak 3 kali sehingga jumlah seluruhnya adalah 36 tanaman. Pelaksanaan penelitian meliputi pembuatan bedengan, pemberian naungan, persiapan media tanam, penanaman kecambah kelapa sawit, pemberian label, pemeliharaan ; pennyiraman, pengendalian hama dan penyakit, pengurangan. Parameter yang diamati ; bobot basah tanaman, bobot kering tanaman, bobot basah daun, bobot basah akar, bobot kering daun dan bobot kering akar. Data yang diperoleh dianalisis dengan menggunakan sidik ragam dan jika terdapat perbedaan yang nyata maka akan dilanjutkan dengan Uji Beda Nyata Terkecil (BNT) pada taraf 5\%.

basah tertinggi adalah pada perlakuan $\mathrm{d}_{2}$ yaitu $5,51 \mathrm{~g}$, sedangkan rata-rata bobot basah terendah terdapat pada perlakuan $\mathrm{d}_{1}$ yaitu $4,82 \mathrm{~g}$. Berdasarkan hasil sidik ragam tampak bahwa perlakuan abu janjang (D) pada perlakuan $23 \mathrm{~g}$ abu janjang/ polybag $\left(\mathrm{d}_{2}\right)$ menghasilkan rata-rata bobot basah terbaik apabila dibandingkan dengan perlakuan abu janjang lainnya. Perlakuan dosis $23 \mathrm{~g}$ abu janjang / polybag $\left(\mathrm{d}_{2}\right)$ telah memberikan unsur-unsur senyawa organik penyusun sel yang telah mencukupi kebutuhan unsur hara bagi tanaman kelapa sawit seperti N, $\mathrm{P}$ dan $\mathrm{K}$ sebagai komponen dalam pembentukan enzim yang dapat meningkatkan pertumbuhan (tinggi tanaman, jumlah daun, diameter pangkal 
Tabel 1. Pengaruh naungan dan abu janjang terhadap rata-rata bobot basah tanaman dan bobot kering bibit kelapa sawit

\begin{tabular}{ccccccc}
\hline \multirow{2}{*}{ Perlakuan } & \multicolumn{3}{c}{ Bobot Basah } & \multicolumn{3}{c}{ Bobot Kering } \\
\cline { 2 - 7 } Naungan & $\begin{array}{c}\text { Tanaman } \\
\text { tn }\end{array}$ & $\begin{array}{c}\text { Daun } \\
\text { tn }\end{array}$ & $\begin{array}{c}\text { Akar } \\
*\end{array}$ & $\begin{array}{c}\text { Tanaman } \\
\text { tn }\end{array}$ & $\begin{array}{c}\text { Daun } \\
\text { tn }\end{array}$ & $\begin{array}{c}\text { Akar } \\
\text { tn }\end{array}$ \\
\hline $\mathrm{n}_{0}$ & 5,07 & 4,61 & $1,69 \mathrm{a}$ & 1,98 & 1,61 & 0,86 \\
$\mathrm{n}_{1}$ & 5,22 & 4,68 & $1,90 \mathrm{~b}$ & 2,15 & 1,70 & 0,97 \\
$\mathrm{n}_{2}$ & 5,22 & 4,49 & $1,84 \mathrm{~b}$ & 2,10 & 1,64 & 0,90 \\
$\mathrm{n}_{3}$ & 4,95 & 4,38 & $1,82 \mathrm{~b}$ & 1,99 & 1,51 & 0,96 \\
Abu Janjang & $*$ & $*$ & tn & $*$ & $*$ & tn \\
$\mathrm{d} 1$ & $4,82 \mathrm{a}$ & $4,14 \mathrm{a}$ & 1,72 & $1,74 \mathrm{a}$ & $1,24 \mathrm{a}$ & 0,90 \\
$\mathrm{~d} 2$ & $5,51 \mathrm{~d}$ & $5,08 \mathrm{~b}$ & 1,87 & $2,32 \mathrm{~d}$ & $1,98 \mathrm{~b}$ & 0,93 \\
$\mathrm{~d} 3$ & $5,20 \mathrm{c}$ & $4,56 \mathrm{a}$ & 1,86 & $2,11 \mathrm{c}$ & $1,64 \mathrm{~b}$ & 0,97 \\
$\mathrm{~d} 4$ & $4,93 \mathrm{ab}$ & $4,38 \mathrm{a}$ & 1,79 & $1,99 \mathrm{~b}$ & $1,60 \mathrm{a}$ & 0,90 \\
$\mathrm{In}$ nteraksi & $\mathrm{tn}$ & $\mathrm{tn}$ & $*$ & tn & tn & tn \\
$\mathrm{n} 0 \mathrm{~d} 1$ & 4,75 & 4,20 & $1,59 \mathrm{a}$ & 1,73 & 1,26 & 0,91 \\
$\mathrm{n} 0 \mathrm{~d} 2$ & 5,48 & 5,04 & $1,80 \mathrm{ab}$ & 2,35 & 2,04 & 0,90 \\
$\mathrm{n} 0 \mathrm{~d} 3$ & 5,28 & 4,84 & $1,76 \mathrm{ab}$ & 2,10 & 1,68 & 0,92 \\
$\mathrm{n} 0 \mathrm{~d} 4$ & 4,78 & 4,36 & $1,61 \mathrm{a}$ & 1,75 & 1,46 & 0,72 \\
$\mathrm{n} 1 \mathrm{~d} 1$ & 4,89 & 4,39 & $1,70 \mathrm{a}$ & 1,68 & 1,25 & 0,89, \\
$\mathrm{n} 1 \mathrm{~d} 2$ & 5,71 & 5,36 & $2,03 \mathrm{c}$ & 2,51 & 2,11 & 1,02 \\
$\mathrm{n} 1 \mathrm{~d} 3$ & 5,12 & 4,60 & $1,86 \mathrm{bc}$ & 2,20 & 1,74 & 1,02 \\
$\mathrm{n} 1 \mathrm{~d} 4$ & 5,16 & 4,39 & $2,00 \mathrm{bc}$ & 2,13 & 1,69 & 0,97 \\
$\mathrm{n} 2 \mathrm{~d} 1$ & 4,98 & 4,12 & $1,60 \mathrm{a}$ & 1,76 & 1,31 & 0,88 \\
$\mathrm{n} 2 \mathrm{~d} 2$ & 5,41 & 5,00 & $1,87 \mathrm{bc}$ & 2,24 & 1,94 & 0,86 \\
$\mathrm{n} 2 \mathrm{~d} 3$ & 5,25 & 4,18 & $2,07 \mathrm{c}$ & 2,12 & 1,62 & 0,94 \\
$\mathrm{n} 2 \mathrm{~d} 4$ & 5,16 & 4,66 & $1,82 \mathrm{bc}$ & 2,20 & 1,71 & 0,93 \\
$\mathrm{n} 3 \mathrm{~d} 1$ & 4,69 & 3,84 & $2,01 \mathrm{bc}$ & 1,71 & 1,15 & 0,92 \\
$\mathrm{n} 3 \mathrm{~d} 2$ & 5,37 & 4,94 & $1,77 \mathrm{a}$ & 2,20 & 1,82 & 0,94 \\
$\mathrm{n} 3 \mathrm{~d} 3$ & 5,12 & 4,64 & $1,77 \mathrm{ab}$ & 2,10 & 1,54 & 1,01 \\
$\mathrm{n} 3 \mathrm{~d} 4$ & 4,62 & 4,12 & $1,74 \mathrm{a}$ & 2,10 & 1,54 & 0,98 \\
\hline
\end{tabular}

Keterangan: Angka rata-rata yang diikuti dengan huruf yang sama menunjukkan berbeda tidak nyata pada uji BNT $5 \%($ BNT d $=0,083,0,41,0,083,0,36 ;$ BNT $\mathrm{n}=0,11$ dan BNT nd $=0,25)$

dari tanaman seperti bertambahnya besar dan berat tanaman dalam kapasitas seimbang dan sesuai bagi kebutuhan tanaman. Diperjelas oleh pendapat Harjadi (1993), apabila translokasi fotosintat dari daun ke bagian tanaman lainnya seperti akar dan batang sangat lancar maka menyebabkan bertambahnya berat segar tanaman, karena persediaan karbohidrat sangat mencukupi untuk kebutuhan akar, batang dan daun.

Media tanam yang digunakan mengandung unsur hara dalam kisaran sedang yang tampak pada hasil analisis kimia tanah terutama $\mathrm{N}$ total adalah $0,25 \%$ ) sehingga dengan demikian tanaman sangat respon terhadap abu janjang yang diberikan terutama pada perlakuan $23 \mathrm{~g}$ abu janjang / polybag $\left(\mathrm{d}_{2}\right)$. Sementara pada perlakuan lainnya dimana terjadi penambahan dosis abu janjang pada perlakuan $45 \mathrm{~g}$ abu janjang / polybag $\left(\mathrm{d}_{4}\right)$ memberikan rata-rata bobot basah terendah. Pada perlakuan $\mathrm{d}_{4}$ mengandung unsur hara yang berlebihan dari kebutuhan tanaman yang dapat menghambat laju pertumbuhan dimana unsur hara yang berlebihan tersebut akan merusak organ tumbuhan terutama pada daun, batang dan akar. Unsur nitrogen $(\mathrm{N})$ yang berlebihan menyebabkan daun lemah dan rentan penyakit, kelebihan unsur hara phospor $(\mathrm{P})$ dan kalium (K) merangsang pertumbuhan akar yang berlebihan sehingga perkembangan batang dan daun terhambat yang mengakibatkan tanaman menjadi kerdil (Harjadi, 2002)

Dilihat dari hasil sidik ragam menunjukkan bahwa perlakuan naungan $(\mathrm{N})$ berbeda tidak nyata terhadap rata-rata bobot basah bibit kelapa sawit. Dapat dilihat hubungan antara naungan dan abu janjang terhadap bobot basah bibit kelapa sawit (Tabel 1), perlakuan naungan dikurangi $50 \%\left(\mathrm{n}_{2}\right)$ memberikan rata-rata bobot basah tertinggi yaitu 5,22 g. Sedangkan rata-rata bobot basah terendah terdapat pada perlakuan naungan naungan dikurangi $25 \%\left(n_{3}\right)$ yaitu 4,95 g. Dapat dikatakan bahwa pada perlakuan naungan $\mathrm{n}_{2}$ merupakan naungan yang sesuai 
untuk mendukung pertumbuhan bibit kelapa sawit, dalam keadaan tersebut naungan dikurangi $50 \% \quad\left(\mathrm{n}_{2}\right)$ menciptakan kesesuaian keadaan lingkungan tumbuh seperti besar kecilnya intensitas cahaya matahari, ketersediaan air, suhu dan kelembapan yang masih dapat dimanfaatkan oleh bibit kelapa sawit untuk melakukan proses fotosintesis sehingga perlakuan pengurangan naungan $50 \%\left(\mathrm{n}_{2}\right)$ berbeda tidak nyata terhadap perlakuan pengurangan naungan $75 \% \quad\left(n_{1}\right)$. Sedangkan pada perlakuan naungan naungan dikurangi $100 \%\left(\mathrm{n}_{0}\right)$ dan naungan dikurangi $25 \%$ $\left(\mathrm{n}_{3}\right)$ menciptakan kondisi yang dapat menghambat pertumbuhan bibit kelapa sawit. Dalam keadaan tanpa naungan pertumbuhan akan terhambat karena tingginya suhu udara sebagai akibat dari tingginya intensitas cahaya matahari yang langsung mengenai tajuk tanaman, sedangkan pada naungan yang terlalu rapat $\left(\mathrm{n}_{3}\right)$ akan menghambat proses fotosintesis dikarenakan jumlah cahaya yang tertahan terlalu besar sehingga proses fotosintesis tidak maksimal yang menyebabkan pertumbuhan menjadi berjalan lambat. Namun keadaan tersebut masih dapat ditoleransi oleh tanaman apabila faktor lain seperti keadaan tanah, ketersediaan air dan unsur hara masih dapat mendukung pertumbuhan sehingga hasil bobot basah yang didapatkan pada masing-masing perlakuan naungan tidak nyata. Intensitas cahaya yang rendah menyebabkan tanaman tanaman berupaya untuk mempertahankan agar fotosintesis tetap berlangsung pada kondisi kekurangan cahaya. Sesuai dengan pendapat Soepandi et al (2003), Kondisi kekurangan cahaya berakibat terganggunya metabolisme, sehingga menyebabkan menurunnya laju fotosintesis dan sintesis karbohidrat.

\section{Bobot Basah Daun}

Hasil sidik ragam menunjukkan bahwa perlakuan naungan $(\mathrm{N})$ berpengaruh tidak nyata, tetapi perlakuan abu janjang (D) memberikan pengaruh nyata terhadap rata-rata bobot basah daun. Hasil uji BNT 5\% menunjukkan bahwa pada perlakuan abu janjang (D) perlakuan $\mathrm{d}_{2}$ berbeda nyata dengan perlakuan $d_{1}, d_{3}$ dan $d_{4}$. Perlakuan $\mathrm{d}_{3}, \mathrm{~d}_{4}$ dan $\mathrm{d}_{1}$ saling tidak berbeda nyata. Rata-rata bobot basah daun tertinggi adalah pada perlakuan $\mathrm{d}_{2}$ yaitu $5,08 \mathrm{~g}$, sedangkan rata-rata bobot basah daun terendah terdapat pada perlakuan $\mathrm{d}_{1}$ yaitu 4,14 g. Berdasarkan hasil analisis sidik ragam menunjukkan perlakuan abu janjang (D) dapat dilihat pada table 3. Rata-rata bobot basah daun tertinggi terdapat pada perlakuan $23 \mathrm{~g}$ abu janjang/polybag (d2) yaitu $5,08 \mathrm{~g}$ dan rata-rata bobot basah daun terendah terdapat pada perlakuan 11,5 g abu janjang/polybag (d1) yaitu 4,14 g.

Perlakuan abu janjang (d) pada perlakuan d2 memberikan rata-rata bobot basah daun tertinggi. Hal ini disebabkan pertumbuhan pucuk didukung oleh pemberian unsur hara yang cukup untuk pertumbuhan bobot basah daun. Unssur nitrogen yang terdapat dalam abu janjang berpengaruh secara tidak langsung terhadap asam amino dan selanjutnya terhadap terbentuknya protein di dalam sel. Protein diperlukan dalam pembelahan dan pembesaran sel pada titik tumbuh tanaman (jumlah helai daun, panjang pelepah dan lingkaran pelepah). Sesuai pendapat Gardner dkk (1991) menyatakan bahwa unsur N merupakan penyusun asam amino, amida, nukeotida dan nukleo protein serta esensial untuk pertumbuhan sel, pembelahan sel yang menyebabkan pertumbuhan pada tanaman.Unsur $\mathrm{P}$ yang ada pada abu janjang berfungsi sebagai komponen dalam menyusun ATP yang diperlukan untuk pembentukan fotosintat dalam proses fotosintesis. Hasil fotosintat yang tinggi dapat memacu pertumbuhan tanaman sehingga berpengaruh terhadap bobot basah daun. Menurut pendapat Gardner dkk (1991) bahwa fosfor merupakan komponen struktur dari jumlah senyawa penting molekul pentransfer ADP dan ATP, NAD, NADPH dan senyawa informasi genetic DNA dan RNA. Senyawa kaya energy dari metabolit penting yang menjadi perantai fosforilasi dan transfer energy. Asam firat menrupakan senyawa cadangan asam fosfat penting yang ditemukan dalam biji. Bentuk $\mathrm{P}$ cadangan ini dapat diremobilisasi untuk menyokong laju metabolis yang tinggi selama perkecambahan biji. Perkecambahan biji kelapa sawit yang vigor dapat memacu pertumbuhan vegetative bibit kelapa sawit. Sehingga menyebabkan meningkatnya bobot basah daun pada pembibitan pre nursery. Unsur K yang ada pada abu janjang berperan dalam proses fotosintesis dengan jumlah $\mathrm{K}$ tersedia bagi tanaman dapat memacu pertumbuhan bibit kelapa sawit yang berhubungan dengan berat bobot basah daun. Hal ini dijelaskan lagi oleh Gardner dkk (1991) bahwa K berperan dalam proses fotosintesis karena secara langsung dapat meningkatkan pertumbuhan dan indek luas daun dan juga dapat meningkatkan asimilasi CO serta meningkatkan translokasi hasil fotosintesis.

\section{Bobot Basah Akar}

Hasil sidik ragam menunjukkan bahwa perlakuan naungan $(\mathrm{N})$ dan interaksi antara perlakuan naungan dan abu janjang berpengaruh nyata, tetapi perlakuan abu janjang (D) memberikan pengaruh tidak nyata terhadap rata- 
rata bobot basah akar. Hasil uji BNT 5\% menunjukkan bahwa pada perlakuan naungan $(\mathrm{N})$ perlakuan $\mathrm{n}_{0}$ berbeda nyata dengan perlakuan $\mathrm{n}_{1}$, $\mathrm{n}_{2}$ dan $\mathrm{n}_{3}$ tetapi ketiganya saling berbeda tidak nyata. Rata-rata bobot basah akar tertinggi adalah pada perlakuan $\mathrm{n}_{1}$ yaitu $1,90 \mathrm{~g}$, sedangkan ratarata bobot basah akar terendah terdapat pada perlakuan $\mathrm{n}_{0}$ yaitu 1,69 g. Hasil uji BNT 5\% menunjukkan bahwa pada interaksi perlakuan naungan dan abu janjang (ND) perlakuan $\mathrm{n}_{2} \mathrm{~d}_{3}$, $\mathrm{n}_{1} \mathrm{~d}_{2}$, berbeda nyata dengan perlakuan $\mathrm{n}_{3} \mathrm{~d}_{4}, \mathrm{n}_{0} \mathrm{~d}_{4}$, $\mathrm{n}_{3} \mathrm{~d}_{3}, \mathrm{n}_{0} \mathrm{~d}_{3}, \mathrm{n}_{3} \mathrm{~d}_{2}, \mathrm{n}_{0} \mathrm{~d}_{2}, \mathrm{n}_{0} \mathrm{~d}_{1}, \mathrm{n}_{1} \mathrm{~d}_{1}$, dan $\mathrm{n}_{2} \mathrm{~d}_{1}$ tetapi berbeda tidak nyata terhadap $\mathrm{n}_{3} \mathrm{~d}_{1}, \mathrm{n}_{2} \mathrm{~d}_{2}, \mathrm{n}_{1} \mathrm{~d}_{3}$, $\mathrm{n}_{1} \mathrm{~d}_{4}$, dan $\mathrm{n}_{2} \mathrm{~d}_{4}$. Sedangkan kelima perlakuan tersebut saling tidak berbeda nyata. Rata-rata bobot basah akar tertinggi adalah pada perlakuan $\mathrm{n}_{2} \mathrm{~d}_{3}$ yaitu $2,07 \mathrm{~g}$, sedangkan rata-rata bobot basah akar terendah terdapat pada perlakuan $\mathrm{n}_{0} \mathrm{~d}_{1}$ yaitu 1,59 g. Berdasarkan hasil penelitian menunjukkan berbeda nyata pada perlakuan naungan $(\mathrm{N})$ dimana yang mendapat naungan dapat merangsang pertumbuhan akar karena media tanaman dalam kondisi yang menguntungkan untuk perkembangan akar dibandingkan tanpa naungan. Kandungan air dalam media tanam tersedia karena evapotranspirasi berjalan lebih lambat, temperature dan kelembaban sehingga proses penyerapan air berjalan lebih cepat untuk digunakan dalam proses fotosintesis dan hasilnya untuk pertumbuhan akar tanaman. Pada interaksi $\mathrm{n} 2 \mathrm{~d} 3$ merupakan hasil yang tertinggi dari berat akar. Hal ini disebabkan karena dengan adanya naungan (n2) diikuti dengan pemberian abu janjang (d3) mempercepat terjadinya proses fotosintesis yang fotosintat dapat digunakan untuk pertumbuhan akar.

\section{Bobot Kering Tanaman}

Hasil sidik ragam menunjukkan bahwa perlakuan naungan $(\mathrm{N})$ berpengaruh tidak nyata, tetapi perlakuan abu janjang (D) memberikan pengaruh nyata terhadap rata-rata bobot kering pertanaman. Hasil rata-rata bobot kering tanaman Kelapa Sawit dapat dilihat pada Tabel 1. Hasil uji BNT 5\% menunjukan bahwa pada perlakuan abu janjang (D) perlakuan $d_{1}$ berbeda nyata dengan perlakuan $d_{2}, d_{3}$ dan $d_{4}$. Perlakuan $d_{2}$ berbeda nyata dengan perlakuan $d_{3}, d_{4}$ dan $d_{1}$. Perlakuan $d_{3}$ berbeda nyata terhadap perlakuan $d_{4}, d_{1}$ dan $d_{2}$. Perlakuan $\mathrm{d}_{4}$ berbeda nyata terhadap perlakuan $\mathrm{d}_{1}$, $\mathrm{d}_{2}$ dan $\mathrm{d}_{3}$. Rata-rata bobot kering tertinggi adalah pada perlakuan $\mathrm{d}_{2}$ yaitu $2,32 \mathrm{~g}$, sedangkan ratarata bobot kering terendah terdapat pada perlakuan $d_{1}$ yaitu $1,74 \mathrm{~g}$. Berdasarkan hasil analisis sidik ragam menunjukkan perlakuan abu janjang (D) berbeda nyata terhadap rata-rata bobot kering tanaman kelapa sawit. Rata-rata bobot kering tertinggi terdapat pada perlakuan 23 g abu janjang / polybag $\left(\mathrm{d}_{2}\right)$ yaitu 2,32 g dan ratarata bobot kering terendah terdapat pada perlakuan 11,5 $\mathrm{g}$ abu janjang / polybag $\left(\mathrm{d}_{1}\right)$ yaitu 1,74 g. Perlakuan abu janjang (D) pada perlakuan 23 g abu janjang / polybag memberikan rata-rata berat kering terbaik, hal tersebut dikarenakan pada masa pertumbuhannya tanaman mendapatkan unsur hara yang sesuai dengan kebutuhan pertumbuhannya pada dosis abu janjang $23 \mathrm{~g}$ abu janjang / polybag $\left(\mathrm{d}_{2}\right)$ untuk mendukung pertumbuhan vegetatifnya (tinggi tanaman, jumlah daun, diameter pangkal batang dan panjang pelepah). Tanaman sangat membutuhkan unsur hara seperti $\mathrm{N}, \mathrm{P}$ dan $\mathrm{K}$ dalam kisaran yang cukup untuk mendukung perumbuhan pada masa vegetatifnya. Lingga (2000), menyatakan bahwa nitrogen pada tanaman berfungsi merangsang pertumbuhan tanaman secara keseluruhan khususnya pada batang, cabang dan daun. Klorofil sangat berperan pada proses fotosintesis dalam menghasilkan karbohidrat sebagai sumber energi juga protein yang sangat dibutuhkan dalam proses pembelahan dan pembesaran sel.

Penambahan unsur hara pada media tanam melalui pemberian abu janjang dapat meningkatkan ketersediaan karbohidrat oleh tanaman yang dihasilkan melalui proses fotosintesis sehingga biomassa tanaman meningkat pula. Menurut Lakitan (1995), berat kering tanaman mencerminkan akumulasi senyawa organik yang berhasil disentesis tanaman dari senyawa organik, terutama air dan karbon dioksida $\left(\mathrm{CO}_{2}\right)$. Unsur hara yang telah diserap akar, baik yang digunakan dalam sintesis senyawa organik maupun yang tetap dalam ionik dalam jaringan tanaman akan memberikan kontribusi terhadap pertambahan berat kering tanaman. Sesuai pendapat Jumin (2005), bahwa berat kering tanaman merupakan penumpukan hasil fotosintesis pada sel dan jaringan tanaman.

\section{Bobot Kering Daun}

Hasil sidik ragam menunjukkan bahwa perlakuan naungan $(\mathrm{N})$ berpengaruh tidak nyata, tetapi perlakuan abu janjang (D) memberikan pengaruh nyata terhadap rata-rata bobot kering daun. Hasil uji BNT 5\% menunjukkan bahwa pada perlakuan abu janjang (D) perlakuan $\mathrm{d}_{2}$ dan $\mathrm{d}_{3}$ saling berbeda tidak nyata tetapi keduanya berbeda nyata terhadap perlakuan $d_{4}$ dan $d_{1}$. Sedangkan perlakuan $\mathrm{d}_{4}$, dan $\mathrm{d}_{1}$ saling tidak berbeda nyata. Rata-rata bobot kering daun tertinggi adalah pada perlakuan $\mathrm{d}_{2}$ yaitu $1,98 \mathrm{~g}$, sedangkan rata-rata bobot kering daun terendah terdapat pada perlakuan $\mathrm{d}_{1}$ yaitu $1,24 \mathrm{~g}$. 
Bobot basah daun yang tertinggi dihasilkan pada perlakuan $\mathrm{d} 1$ dan bobot kering daun tertinggi pada perlakuan $\mathrm{d} 2$ dan $\mathrm{d} 3$. Hal ini disebabkan hubungan antara $\mathrm{d} 2$ berat basah daun dan dengan berat kering daun (d2) setelah tanpa ada kandungan air, tetapi pada berat daun kering meningkat (d3) dibandingkan dengan berat basah daun (d2). Hal ini kandungan air yang ada pada tanaman lebih sedikit. Hasil fotosintat lebih banyak disimpan di daun dengan meningkatnya dosis abu janjang yang diberikan dapat meningkatkan bahan kering tanaman, walaupun perlakuan $\mathrm{d} 2$ berbeda tidak nyata dengan $\mathrm{d} 3$.

\section{Bobot Kering Akar}

Hasil sidik ragam menunjukkan bahwa perlakuan naungan (N) dan abu janjang (D) memberikan pengaruh tidak nyata terhadap ratarata bobot kering akar.

Dari hasil penelitian berat kering akar berbeda tidak nyata untuk semua perlakuan. Hal ini unsure hara dan naungan mempunyai respon yang sama terhadap pertumbuhan akar dimana hasil fotosintesis dalam bentuk fotosintat disimpan di jaringan akar. Pada bobot basah akar perlakuan $\mathrm{n} 2 \mathrm{~d} 3$ memberikan hasil tertinggi. Hal ini disebabkan jumlah air dalam sel lebih banyak diserap karena lingkungan dalam kondisi yang menguntungkan untuk penyerapan air sedangkan

\section{DAFTAR PUSTAKA}

Asmono, D. 2003. Budidaya kelapa sawit. Pusat Penelitian Kelapa Sawit (IOPRI), Medan.

Dinas Perkebunan Kalimantan Timur. 2009. Perkembangan Perkebunan Kelapa Sawit. http://www.poskotakaltim.com/berita/read/69 69-areal-sawit-kaltim-capai-530.555-ha.html

Dwijoseputro. 1992. Pengantar Fisiologi Tumbuhan. Gramedia Pustaka Utama, Jakarta.

Fitter, AH., dan RKM. Hay. 1992. Fisiologi Lingkungan Tanaman. Gajah Mada University Press, Yogyakarta.

Gardner FP, Pearce RB, and Mitchell RL. 1991. Physiology of Crop Plants. Diterjemahkan oleh H. Susilo. Jakarta. Universitas Indonesia Press.

Harjadi. S.S. 2002. Pengantar Agronomi. Gramedia Pustaka Utama, Jakarta. unsure hara yang ada sudah terbatas untuk semua perlakuan dalam bentuk fotosintat dan ditransfer ke dalam jaringan akar.

\section{KESIMPULAN}

1. Perlakuan naungan memberikan pengaruh nyata terhadap rata-rata bobot basah akar tetapi memberikan pengaruh tidak nyata terhadap rata-rata bobot basah, bobot kering, bobot basah daun, bobot kering daun daun bobot kering akar.

2. Perlakuan abu janjang memberikan pengaruh nyata terhadap rata-rata bobot basah, bobot kering, bobot basah daun, bobot basah akar, bobot kering daun tetapi memberikan pengaruh tidak nyata terhadap bobot kering akar.

3. Perlakuan abu janjang $\left(\mathrm{d}_{2}\right)$ memberikan bobot basah, bobot kering, bobot basah daun, bobot kering daun rata-rata 5,51 g, 2,32 g, dan $5,08 \mathrm{~g}$.

4. Perlakuan naungan memberikan bobot basah akar rata-rata $1,90 \mathrm{~g}$.

Jumin, H, B. 2005. Dasar-Dasar Agronomi. Raja Grafindo Persada, Jakarta.

Karyudi. 1991. Pengaruh Abu Janjang Kelapa Sawit Terhadap Pertumbuhan Semaian Karet. Abstrak Hasil Penelitian Badan Litbang Pertanian, Medan.

Kuswandi. 1989. Pengapuran Tanah Pertanian. Tim Redaksi Trubus. Jakarta.

Lakitan, B. 1995. Hortikultura. Raja Grafindo Persada, Kalimantan Timur.

Lingga, P. 2000. Petunjuk Penggunaan Pupuk. Penebar Swadaya, Jakarta.

Lubis, A. U. 2000. Pemetaan Dan Jenis Tanah Perkebunan Kelapa Sawit di Sumatra Utara. Buletin PPM Volume 3 No 2. Marihat Research. Marihat Ulu, Medan.

Magfoer dan Koesriharti. 1998. Rekayasa Teknologi Naungan Dalam Sistem Budidaya Paprika (Capsicum Annum L). Jurnal Penelitian Ilmu-Ilmu Teknik (Engeneering) 10 (1) : 89-95. 
Maspary. 2010. Fungsi Unsur Hara Dalam Proses Pertumbuhan dan Perkembangan Tanaman. dalam http://www.gerbangpertanian.com/2010/04/f ungsi-unsur-hara-bagi-pertumbuhandan.html 
J. Agrifarm : Vol. 6 No. 1, Juli 2017 ISSN : 2301 - 9700 